\title{
Comparison of extraction methods for selected carotenoids from macroalgae and the assessment of their seasonal/spatial variation.
}

\author{
N. Heffernan ${ }^{1,3}$, T. J. Smyth ${ }^{2 *}$, Richard J. FitzGerald ${ }^{3}$, Anna Vila-Soler ${ }^{4}$, J. Mendiola ${ }^{5}$, \\ E. Ibáñez ${ }^{5}$, N. P. Brunton ${ }^{6}$.
}

1. Food Biosciences Department, Teagasc Food Research Centre, Ashtown, Dublin 15, Ireland

2. Department of Life Sciences, Institute of Technology, Sligo, Ireland

3. Department of Life Science, University of Limerick, Limerick, Ireland

4. Irish Seaweed Research Group, Ryan Institute (Environmental Marine and Energy Research), National University of Ireland Galway, Galway, Ireland.

5. Institute of Food Science Research CIAL (CSIC-UAM), Madrid, Spain.

6. School of Agriculture and Food Science, University College Dublin, Belfield, Dublin 4, Ireland

"Corresponding author: smyth.thomas@itsligo.ie

\begin{abstract}
Natural bioactives are an excellent source of carotenoids for the production of nutraceuticals, functional foods and food additives. The extraction efficiencies of solid-liquid extraction (SLE), supercritical $\mathrm{CO}_{2}$, supercritical $\mathrm{CO}_{2}$ with ethanol as co-solvent for the recovery of the carotenoids, xanthophyll and fucoxanthin, from two brown macroalgae Fucus serratus and Laminaria digitata were explored. The extraction efficiency was measured using both purity and yield of target compounds. Solid liquid extraction (hexane/acetone (70:30) at $50^{\circ} \mathrm{C}$ for
\end{abstract}


$24 \mathrm{~h}$ produced the greatest yield of carotenoid rich extracts from Fucus serratus. Optimal conditions in terms of carotenoid yield using supercritical $\mathrm{CO}_{2}$ were $50^{\circ} \mathrm{C}, 300 \mathrm{Atm}$ with an extraction time of $60 \mathrm{~min} . \mathrm{SCO}_{2}$ yielded a higher purity of fucoxanthin while SLE resulted in a higher purity of xanthophyll. Seasonal/spatial variation based on the purity and yield was also investigated to provide valuable information on optimal harvest time for these compounds.

Keywords; Macroalgae, supercritical $\mathrm{CO}_{2}$ extraction, carotenoids, fucoxanthin, xanthophyll.

\subsection{Introduction}

A range of natural sources are currently being explored as novel and sustainable sources of compounds for both pharmaceutical and nutraceutical applications (Barbosa et al., 2014: Duan et al., 2006; Park et al., 2004). The successful commercialisation of these natural resources is highly dependent on the identification of technologies capable of recovering target compounds in a clean, efficient and low-cost manner. Supercritical fluid extraction (SFE) has long been touted as a clean, cost effective and energy efficient method for recovering target compounds from natural matrices. The technique is most commonly used with $\mathrm{CO}_{2}$ as the supercritical solvent making it particularly efficient for hydrophobic compounds such as carotenoids. Carotenoids are highly conjugated polyprenoid compounds with two terminal ring systems. Carotenoids composed entirely of carbon and hydrogen are known as carotenes which are orange in colour, while those that contain oxygen are known as xanthophylls and are yellow in colour. Fucoxanthin is characterised by the presence of an allene group and is one of the most abundant marine carotenoids (Dembitsky and Maoka, 
2007) especially in brown macroalgae (Peng et al., 2011). Generally fucoxanthins are polygenic carotenoids with linear conjugated double bonds as observed for $\beta$-carotene (Figure 1). Fucoxanthin is purported to have antioxidant (Sachindra et al., 2007; Airanthi et al., 2011; Fung et al., 2013), anti-inflammatory (Heo et al., 2008; Kim et al., 2010; Heo et al., 2012), anti-cancer (Miki, 1991; Miyashita et al., 2011), anti-obesity (Maeda et al., 2005; Gammone and D’Orazio, 2015), anti-diabetic (Maeda et al., 2007; Hosokawa et al., 2010; Nishikawa et al., 2012), hepatoprotective (Woo et al., 2010) and skin-protective effects (Heo and Jeon, 2009; Urikura et al., 2011). It therefore could be exploited for potential uses in both the pharmaceutical and food industries. Carotenoid content in macroalgae is known to vary in some species according to season, while they can also differ in brown algae collected in different locations (Nomura et al., 2013). However, whilst several studies on the content of photosynthetic pigments of algae under investigation in the present study have been carried out (Aguilera et al., 2002; Gudrum, 2005; Sarojini, 2009; Schmidt et al., 2010), limited information is available on the seasonal changes that can occur. Considering any marine hydrobionts as a source of carotenoids or functional food components, determining the optimal period of harvesting algae with maximal content of these valuable substances is required.

Carotenoids can also be extracted from marine algae using organic solvents. However the majority of organic solvents are often expensive and potentially harmful to the environment and in food processing have the potential for solvent residue contamination of the final products. In fact regulations in Europe and elsewhere relating to extraction solvents for use in foodstuffs provide detailed guidelines that have to be strictly adhered to for the protection of human health, economic and technical needs (Anon, 2009). Therefore the use of clean, simple, fast and more efficient technologies for the extraction of carotenoids from natural sources (Mohamed and Mansoori, 2002) would be highly desirable. Supercritical fluids offer 
many advantages such as a higher diffusion coefficient and lower viscosity than liquids, while the reduced surface tension allows for their rapid penetration into the pores of hetergeneous matrices enhancing extraction efficiencies (Eggers and Lack, 2012). Selectivity during extraction may be controlled by varying the conditions of temperature and pressure, thus affecting the solubility of the various components in the supercritical fluid. Supercritical fluids such as carbon dioxide do not leave a chemical residue and can be recycled and used again as part of the unit operation (Rizvi et al., 1994; Shilpi et al., 2013). A known limitation of supercritical $\mathrm{CO}_{2}$ is that it often fails in complete extraction of polar analytes from solid matrices, because of the solvating ability of this fluid and the insufficient interaction between $\mathrm{CO}_{2}$ and the matrix. The use of an organic modifier has proven to greatly improve the extraction efficiency (Hamburger et al., 2004) by increasing the solubility of the analytes, by reducing their interaction with the sample matrix or by inducing matrix modification resulting in the release of the analytes from the matrix being greatly enhanced.

This study has two main aims, [1] investigate the various extraction techniques for the extraction of the common carotenoids, fucoxanthin and xanthophyll (a synonym of lutein) found in macroalgae and [2] to apply these methods to investigate the seasonal/spatial variation of these compounds over the period of a year.

\subsection{Materials and Methods}

\subsection{Chemicals}

$\mathrm{CO}_{2}$ (N-38 quality) was obtained from AirLiquideEspaňa S. A. (Madrid, Spain). Ethanol was purchased from Sigma Aldrich (Madrid, Spain), Laboratory grade sea sand was purchased from Fluka (Madrid, Spain). HPLC grade acetone, hexane, methanol and water and the internal standards fucoxanthin and xanthophyll were purchased from Sigma Aldrich (Dublin Ireland). 


\subsection{Samples}

The brown macroalgae samples used in this study were identified and harvested off the west coast of Ireland. Fucus serratus and Laminaria digitata was harvested from two locations

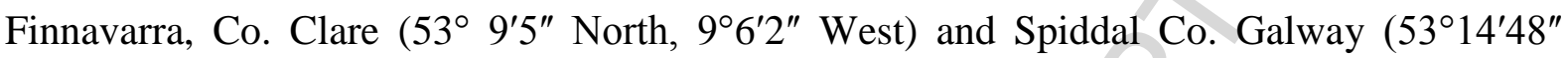
North, $9^{\circ} 18^{\prime} 10^{\prime \prime}$ West) over the period of a year from 2011-2012. A random selection of different plants were taken from the shore, to allow for natural variability, these were packed in cool boxes and transported immediately to the laboratory. Samples were washed thoroughly with fresh water to remove sand and epiphytes and were then stored in the freezer at $-20{ }^{\circ} \mathrm{C}$. The identity of each macroalgal specimen was verified and a freeze dried sample of each was retained for reference at the Irish Seaweed Centre at NUIG. The macroalgal samples were subsequently freeze dried and ground to a powder using a Waring® blender (New Hartford, CT, USA) and stored in vacuum packed bags at $-80{ }^{\circ} \mathrm{C}$ prior to extraction.

\subsection{Solid-Liquid extraction (SLE)}

Solid liquid extraction was employed to extract the carotenoids from the macroalgae under investigation using hexane/acetone (70:30) as this solvent system has previously been shown to be effective for extracting pigments from plant materials (AOAC, 1984; Torres et al., 2014). Crude extracts were prepared by placing $10 \mathrm{~g}$ of the seaweed powder in a conical flask and adding the extraction solvent hexane/acetone (70:30) at a ratio of 10:1 (v/w). The mixture was then placed into a shaker (Thermo Scientific MaxQ6000) at room temperature for 24 hours. These extracts were filtered three times over a 24 hour period through a Buchner funnel. The combined extracts were concentrated to remove all solvent using a rotary evaporator (BüchiRotavapour R-200 with a V710 vacuum pump) with the water bath set at $50{ }^{\circ} \mathrm{C}$. 


\subsection{Optimization of Supercritical Carbon dioxide $\left(\mathrm{SCO}_{2}\right)$ extraction}

A SuprexPrep Master (Suprex, Pittsburgh, PA) extractor was used for the $\mathrm{SCO}_{2}$ extraction optimization. Prior to starting extractions, optimization of the extraction time and conditions was determined. The extractor was equipped with a dual piston pump for $\mathrm{CO}_{2}$. Pressure in the extractor was controlled by a back regulator valve and the extraction vessel was heated to optimal temperature in an oven. $2 \mathrm{~g}$ of sample and $4 \mathrm{~g}$ of sea sand were loaded into a $20 \mathrm{~mL}$ stainless steel extraction cell with the cell fitted with glass wool at the inlet and outlet. To determine extraction conditions, extractions were performed at three different extraction temperatures $\left(30,40 \& 50{ }^{\circ} \mathrm{C}\right)$ and at three different pressures $(150,225 \& 300 \mathrm{Atm})$ for each temperature. Optimal conditions were chosen based on the extract yield obtained for each test parameter (fucoxanthin and xanthophyll). To optimize extraction time, a time versus yield curve was constructed (extraction kinetic study) at $50{ }^{\circ} \mathrm{C}$ and $300 \mathrm{Atm}$. The extract yield was measured in grams at 15 min intervals to determine when the extract was exhaustively extracted and thus allowing for optimum carotenoid extraction.

\subsection{Supercritical $\mathrm{CO}_{2}$ Extraction $\left(\mathrm{SCO}_{2}\right)$}

Extraction of carotenoids for seasonal and geographical studies was carried out using the optimal extraction conditions as described in $3.1\left(50{ }^{\circ} \mathrm{C}, 300 \mathrm{Atm}\right.$ and an extraction time of $105 \mathrm{~min}, \mathrm{CO}_{2}$ flow rate $10 \mathrm{~mL} / \mathrm{min}$ ) but using a larger scale apparatus Spe-ed SFE Helix (Applied Separations, Allentown, USA). Extracts were prepared using $30 \mathrm{~g}$ of freeze dried seaweed powder mixed with $90 \mathrm{~g}$ of laboratory grade sea sand in a 0.5 litre stainless steel extraction cell. The extraction cell was packed with glass wool at the inlet and outlet. Extracts were collected in a sterile vessel and cooled by ice. The extracts were dried under a stream of nitrogen and stored at $-20^{\circ} \mathrm{C}$. 


\subsection{Supercritical $\mathrm{CO}_{2}$ Extraction with ethanol as co-solvent $\left(\mathrm{SCO}_{2} / \mathrm{EtOH}\right)$}

A SuprexPrep Master (Suprex, Pittsburgh, PA) was used for Supercritical fluid extraction studies using ethanol as co-solvent. The extractor was equipped with a dual piston pump for $\mathrm{CO}_{2} .2 \mathrm{~g}$ of seaweed sample was mixed with $4.0 \mathrm{~g}$ of laboratory grade sea sand and the mixture was loaded into a $20 \mathrm{~mL}$ stainless steel extraction cell. The extraction cell was fitted with glass wool at the inlet and outlet. Ethanol was pumped at $0.1 \mathrm{~mL} / \mathrm{min}$ using a Jasco PU2080 HPLC pump (Jasco Inc., Tokyo, Japan) and mixed at high pressure with supercritical $\mathrm{CO}_{2}\left(\mathrm{SC}-\mathrm{CO}_{2}\right)$ which was pumped at $1 \mathrm{~mL} / \mathrm{min}$. Extraction conditions were as described in section $3.2\left(50{ }^{\circ} \mathrm{C}, 300 \mathrm{Atm}\right.$ and $60 \mathrm{~min}$ extraction time). To ensure all ethanol was purged from the system and there was no carry over between extractions for the final 15 minutes only $\mathrm{CO}_{2}$ was applied. Extracts were collected in a sterile vessel and cooled on ice. To avoid sample degradation, the extracts were stored at $-20{ }^{\circ} \mathrm{C}$ and protected from light until the drying step. Extracts were subsequently dried under a stream of nitrogen.

\subsection{Analysis of Carotenoids by HPLC-DAD}

The carotenoid extracts were analysed using HPLC (Waters Alliance 2695-Separations Module with Empower Pro Software 2002) equipped with a diode array detector (DAD) (Waters 996) with an absorbance range between 190 and $650 \mathrm{~nm}$. Separation was carried out

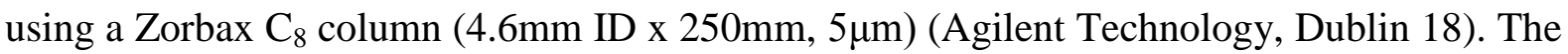
mobile phase, a mixture of solvent A (methanol) and solvent $\mathrm{B}$ (water) at $1 \mathrm{~mL} / \mathrm{min}^{-1}$ was varied according to a step gradient, lasting $30 \mathrm{~min}$, which started from $85 \% \mathrm{~B}$, changing to $100 \%$ B over 15 min and kept at $100 \%$ B until 28.5 min followed by $85 \%$ B at 29.0 mins held for one minute. Dried sample extracts were prepared at a concentration of $5 \mathrm{mg} / \mathrm{ml}$ and a $20 \mu \mathrm{L}$ injection volume was used throughout. A fucoxanthin calibration curve $\left(\mathrm{R}^{2}=0.9921\right)$ 
was obtained by injecting fucoxanthin standard at concentrations ranging from 0.005 to 0.05 $\mathrm{mg} / \mathrm{mL}$. A xanthophyll calibration curve $\left(\mathrm{R}^{2}=0.9933\right)$ was obtained by injecting xanthophyll standard at concentrations ranging from 0.0005 to $0.050 \mathrm{mg} / \mathrm{mL}$. All of the calibration points were injected in duplicate. The purity of both fucoxanthin and xanthophyll were determined from their standard curves respectively, and were expressed as milligram Fucoxanthin equivalents per milligram extract (mg FE/mg extract) and milligram Xanthophyll equivalents per milligram extract (mg XE/mg extract). The total content of both Fucoxanthin and Xanthophyll were determined by multiplying the calculated purity by the total extract yield, these were expressed at the Total Fucoxanthin content (TFC) in milligrams per gram dry weight extract (mg TFC/g DWE) and Total Xanthophyll content (TXC) in milligrams per gram dry weight extract (mg TXC/g DWE).

\subsection{Statistical analysis}

All extracts were analysed in duplicate. Measurement values are presented in means \pm standard deviation. One way analysis of variance (ANOVA), followed by the Tukey post hoc comparison test, was carried out to test for significant differences using the statistical program Minitab ${ }^{\circledR}$ Release 15 for Windows. A probability value of $p<0.05$ was considered statistically significant.

\subsection{Results and Discussion}

\subsection{Optimization of SFE extraction}

To ensure sufficient extraction time required to exhaustively extract the compound of interest from the sample, Fucus serratus was extracted over 105 min to determine at what time the 
highest extract yield was obtained using a temperature of $50^{\circ} \mathrm{C}$, a pressure of $300 \mathrm{Atm}$ and a flow rate of $1 \mathrm{ml} / \mathrm{min}$. At 15 minute intervals the collection vessel was weighed and a new vessel added for the next time interval. A plot of time versus cumulative yield was constructed to demonstrate the optimal extraction time (Fig 1.). It can be seen that from 60 min to $105 \mathrm{~min}$ similar yields are obtained ranging from $8.2-8.9 \mathrm{mg} / \mathrm{g}$ extract $(0.20-0.22 \%$ extract yield). Based on these results, and the cost involved in harvesting and preparing the seaweed an extraction time of 60 min was chosen to ensure that maximum extraction of the target compounds would be achieved with minimal waste.

Fucus serratus samples were tested at three different temperatures $\left(30,40 \& 50{ }^{\circ} \mathrm{C}\right)$ and three different pressures $(150,225 \& 300 \mathrm{Atm})$ to determine the conditions resulting in the highest yield of carotenoid extracts (Fig 2.). Results are presented as a percentage of the total extract yield. It was found that the highest temperature tested of $50{ }^{\circ} \mathrm{C}$ and also the highest pressure tested of 300 Atm gave the highest extract yield of $0.49 \%(27.32 \mathrm{mg} / \mathrm{g} \mathrm{DWE})(p<0.05)$. This is similar to that observed for other marine species. Macías-Sánchez et al., (2005) measured yield of pigments (carotenoids and chlorophylls) from microalgae Nannochloropis gaditana at temperatures from $40-60^{\circ} \mathrm{C}$ and pressures ranging from $100-500$ bar, they found that the higher temperature of $50^{\circ} \mathrm{C}$ and the higher pressure of 300 bar gave a greater yield of pigments. Similarly, Mendes et al., (2005) tested a range of temperatures $\left(40-55{ }^{\circ} \mathrm{C}\right)$ and pressures and determined that the higher temperatures and pressures gave the greatest yield of carotenoids from the microalgae Chlorella vulgaris. Roh et al., (2008) also utilised $\mathrm{SCO}_{2}$ for the extraction of fucoxanthin from the macroalgae Undaria pinnatifida using temperature ranging from 303-333 $\mathrm{K}$ and pressures ranging from 80-100 bar, they found that the higher temperatures and pressures of $200 \mathrm{bar}(197.38 \mathrm{Atm})$ and $323 \mathrm{~K}\left(50{ }^{\circ} \mathrm{C}\right)$ along with $250 \mathrm{bar}$ (246.73 Atm) and $333 \mathrm{~K}\left(60^{\circ} \mathrm{C}\right)$ gave the highest yield of fucoxanthin and polyphenols. 


\subsection{Analysis of fucoxanthin and Xanthophyll Content using different extraction methods}

Table 1 presents data for xanthophyll and fucoxanthin from $F$. serratus using conditions which gave the highest yield of carotenoid $\left(300 \mathrm{Atm}, 50^{\circ} \mathrm{C}\right.$ for $60 \mathrm{~min}$ ) using $\mathrm{SCO}_{2}$, solvent extraction (SLE) and $\mathrm{SCO}_{2}$ with ethanol as co-solvent $\left(\mathrm{SCO}_{2} / \mathrm{EtOH}\right)$. The purity of both fucoxanthin and xanthophyll were determined from their standard curves respectively using HPLC, and were expressed as milligram Fucoxanthin equivalents per milligram extract (mg $\mathrm{FE} / \mathrm{mg}$ extract) and milligram Xanthophyll equivalents per milligram extract (mg XE/mg extract). SLE resulted in the highest total extract yield of $27.32 \mathrm{mg} / \mathrm{g}$ DWE (i.e., DW of all components extracted) with $\mathrm{SCO}_{2}$ resulting in the lowest extract yield of $3.2 \mathrm{mg} / \mathrm{g} \mathrm{DWE}$. As well as producing the greatest yield, the SLE technique also produced extracts with the highest total fucoxanthin content (TFC) of $3.57 \mathrm{mg}$ TFC/g DWE and also the highest total xanthophyll content (TXC) of $0.137 \mathrm{mg}$ TXC/g DWE. Roh et al., (2008) found that $\mathrm{SCO}_{2}$ gave a low yield of fucoxanthin of $0.00753 \mu \mathrm{g} / \mathrm{g}$ in freeze dried Undaria pinnatfida. MacíasSánchez et al., (2007) stated that the yield depends on a complex balance in relation to the decrease in the supercritical carbon dioxide density and the increase in vapour pressure of the pigments as the temperature increases, which essentially represents the solubility of the pigment in the solvent.

The purity of both fucoxanthin and xanthophyll were greater for the $\mathrm{SCO}_{2}$ samples, with the purity of fucoxanthin being significantly $(p>0.05)$ lower in the SLE extracts. $\mathrm{SCO}_{2}$ provided the highest purity of Fucoxanthin $(0.151 \mathrm{mg} \mathrm{FE} / \mathrm{mg}$ extract $)$ and also the highest purity of Xanthophyll (0.008 mg XE/mg extract). Xiao et al., (2012) isolated fucoxanthin from edible brown algae by microwave assisted extraction coupled with high speed countercurrent chromatography and investigated the purity of each fucoxanthin fraction. They found the 
purity to range between $86-95 \%$ in fractions isolated from the three brown algae $S$. fusiforme, U. pinnatifida and L. japonica. To the best of our knowledge no studies to date have investigated the purity of fucoxanthin isolated using a range of extraction techniques as in this study.

The purity of fucoxanthin following extraction is tenfold higher than that of xanthophyll. This can be clearly observed in the HPLC chromatogram in Figure 3 (SFE extraction) where the fucoxanthin peak is by far the most abundant with a fucoxanthin purity of $0.151 \mathrm{mg} \mathrm{FE} / \mathrm{mg}$ extract, while the xanthophyll peak is almost 20 times smaller with a xanthophyll purity of $0.008 \mathrm{mg} \mathrm{XE} / \mathrm{mg}$ extract. In the HPLC chromatogram for SFE and co-solvent extraction (Figure 4), fucoxanthin is less prominent and a lower purity of fucoxanthin was observed ( $0.136 \mathrm{mg} \mathrm{FE} / \mathrm{mg}$ extract). The use of the modifier increased the extraction of xanthophyll to a level three fold higher than SFE, however the purity of the xanthophyll $(0.007 \mathrm{mg} \mathrm{XE} / \mathrm{mg}$ extract) was reduced in comparison to SFE. A number of other impurities are also present in the chromatogram that were not observed in the SFE extraction. In Figure 5 (SLE extraction) the levels of both compounds are much higher with the level of fucoxanthin almost tripling and xanthophyll increasing to over three times more than that observed in SFE with cosolvent. However, both the purity of fucoxanthin and xanthophyll were again reduced when compared to the previously discussed extraction methods $(0.131 \mathrm{mg}$ FE/mg extract and 0.005 mg XE/mg extract).

In general therefore SLE delivers the highest total yield of the target compound while $\mathrm{SCO}_{2}$ resulted in the best purity in relation to fucoxanthin. This outcome contrasts with a previous study by Marsili and Callahan (1993) that compared liquid solvent extraction and supercritical fluid extraction for the determination of carotenoids in vegetable. They observed that the SFE gave a higher yield of the carotenoid beta-carotene than the conventional solvent extraction but this could be due to the different matrix effect of the macroalgae. Although 
SLE gave the highest yield it must be noted that the extraction time was carried out over a 24 $\mathrm{h}$ period, while $\mathrm{SCO}_{2}$ with and without co-solvent was carried out over a much shorter extraction time $(<2 \mathrm{~h})$ and gave a much lower yield. $\mathrm{SCO}_{2}$ therefore consumes less energy during extraction while increasing through-put which is often more desirable to processors. Also the targeted nature of $\mathrm{SCO}_{2}$ extraction may also be attractive if for obtaining a more pure sample. 
Table 1. Extract yield (mg/g dry weight extract (DWE)), fucoxanthin purity (mg fucoxanthin equivalents(FE)/mg extract), xanthophyll purity (mg xanthophylls equivalents (XE)/mg extract), Total fucoxanthin content (TFC) (mg TFC/g dry weight extract (DWE)) and Total Xanthophyll content (TXC) (mg TXE/g dry weight extract (DWE)) from optimised extraction conditions on Fucus serratus, using supercritical fluid extraction $\left(\mathrm{SCO}_{2}\right)$, solid-liquid extraction (SLE) and $\mathrm{SCO}_{2}$ with ethanol as co-solvent $\left(\mathrm{SCO}_{2} / \mathrm{EtOH}\right)$.

\begin{tabular}{|c|c|c|c|c|c|}
\hline Extractions & Total extract yield (mg/g DWE) & $\begin{array}{c}\text { Fucoxanthin purity (mg } \\
\text { FE/mg extract) }\end{array}$ & $\begin{array}{c}\text { Xanthophyll purity (mg } \\
\text { XE/mg extract) }\end{array}$ & $\begin{array}{c}\text { Total Fucoxanthin } \\
\text { content (mg TFC/g } \\
\text { DWE) }\end{array}$ & $\begin{array}{c}\text { Total Xanthophyll } \\
\text { content (mg TXC/g } \\
\text { DWE) } \\
\end{array}$ \\
\hline SLE & $27.32^{\mathrm{a}}$ & $0.131 \pm 0.003^{\mathrm{b}}$ & $0.005 \pm 0.001^{\mathrm{b}}$ & $3.57^{\mathrm{a}}$ & $0.137^{\mathrm{a}}$ \\
\hline $\mathrm{SCO}_{2} / \mathrm{EtOH}$ & $16.00^{\mathrm{b}}$ & $0.136 \pm 0.002^{\mathrm{b}}$ & $0.007 \pm 0.003^{b}$ & $2.18^{\mathrm{b}}$ & $0.112^{\mathrm{a}}$ \\
\hline $\mathrm{SCO}_{2}$ & $3.20^{\mathrm{c}}$ & $0.151 \pm 0.006^{\mathrm{a}}$ & $0.008 \pm 0.006^{\mathrm{a}}$ & $0.51^{\mathrm{c}}$ & $0.027^{\mathrm{b}}$ \\
\hline
\end{tabular}


Table 2. Fucoxanthin purity (mg fucoxanthin equivalents(FE)/mg extract) and Xanthophyll purity (mg xanthophylls equivalents (XE)/mg extract), and total extract yield (mg/g dry weight extract(DWE)) of solid-liquids extracts (SLE), supercritical fluid extracts (SFE) and supercritical fluid extracts with ethanol as co-solvent, Total Fucoxanthin content (TFC) (mg TFC/g dry weight extract (DWE)) and Total Xanthophyll content (TXC) (mg TXE/g dry weight extract (DWE)) of Laminaria digitata over four seasons and from two harvest locations.

\begin{tabular}{|c|c|c|c|c|c|c|c|}
\hline Extract & Location & Season & $\begin{array}{l}\text { Fucoxanthin purity } \\
\text { (mg FE/mg extract) } \\
\text { Laminaria digitata }\end{array}$ & $\begin{array}{c}\text { Xanthophyll purity } \\
\text { (mg XE/mg extract) } \\
\text { Laminaria digitata }\end{array}$ & $\begin{array}{l}\text { Extract yield } \\
\text { (mg/g DWE) }\end{array}$ & $\begin{array}{c}\text { Total Fucoxanthin } \\
\text { content (mg TFC/g DWE) } \\
\text { in Lamianria digitata }\end{array}$ & $\begin{array}{c}\text { Total Xanthophyll Conten } \\
\text { (mg TXC/g DWE) in } \\
\text { Laminaria digitata }\end{array}$ \\
\hline SLE & Finnavarra & Spring & $0.180 \pm 0.003^{\mathrm{abc}}$ & $0.015 \pm 0.003^{\mathrm{a}}$ & 4.69 & $0.844 \pm 0.004^{\mathrm{g}}$ & $0.070 \pm 0.002^{\mathrm{a}}$ \\
\hline SLE & Spiddal & Spring & $0.190 \pm 0.006^{\mathrm{a}}$ & $0.014 \pm 0.006^{\mathrm{a}}$ & 3.91 & $0.743 \pm 0.007^{\mathrm{i}}$ & $0.055 \pm 0.005^{\mathrm{b}}$ \\
\hline SLE & Finnavarra & Summer & $0.154 \pm 0.001^{\mathrm{defgh}}$ & $0.008 \pm 0.001^{\mathrm{b}}$ & 3.19 & $0.491 \pm 0.000^{\mathrm{k}}$ & $0.026 \pm 0.004^{\mathrm{def}}$ \\
\hline SLE & Spiddal & Summer & $0.159 \pm 0.000^{\mathrm{def}}$ & $0.009 \pm 0.000^{\mathrm{b}}$ & 4.60 & $0.731 \pm 0.003^{\mathrm{i}}$ & $0.041 \pm 0.004^{\mathrm{c}}$ \\
\hline SLE & Finnavarra & Autumn & $0.130 \pm 0.013^{\mathrm{i}}$ & $0.002 \pm 0.013^{\mathrm{d}}$ & 4.28 & $0.556 \pm 0.004^{\mathrm{j}}$ & $0.009 \pm 0.002^{\mathrm{gh}}$ \\
\hline SLE & Spiddal & Autumn & $0.134 \pm 0.003^{\mathrm{i}}$ & $0.002 \pm 0.010^{\mathrm{d}}$ & 6.41 & $0.859 \pm 0.003^{\mathrm{g}}$ & $0.013 \pm 0.002^{\mathrm{fgh}}$ \\
\hline SLE & Finnavarra & Winter & $0.142 \pm 0.004^{\text {fghi }}$ & $0.005 \pm 0.004^{\mathrm{c}}$ & 3.19 & $0.450 \pm 0.005^{1}$ & $0.016 \pm 0.005^{\text {efgh }}$ \\
\hline SLE & Spiddal & Winter & $0.170 \pm 0.004^{\mathrm{bcd}}$ & $0.008 \pm 0.005^{b}$ & 8.25 & $1.403 \pm 0.007^{\mathrm{a}}$ & $0.066 \pm 0.004^{\mathrm{ab}}$ \\
\hline $\mathrm{SCO}_{2} / \mathrm{EtOH}$ & Finnavarra & Spring & $0.138 \pm 0.001^{\mathrm{ghi}}$ & $0.003 \pm 0.001^{\mathrm{a}}$ & 7.00 & $0.946 \pm 0.006^{\mathrm{e}}$ & $0.021 \pm 0.003^{\operatorname{defg}}$ \\
\hline $\mathrm{SCO}_{2} / \mathrm{EtOH}$ & Spiddal & Spring & $0.140 \pm 0.004^{\text {fghi }}$ & $0.004 \pm 0.004^{\mathrm{a}}$ & 8.00 & $1.123 \pm 0.007^{\mathrm{c}}$ & $0.032 \pm 0.006^{\mathrm{cd}}$ \\
\hline $\mathrm{SCO}_{2} / \mathrm{EtOH}$ & Finnavarra & Summer & $0.139 \pm 0.000^{\text {ghi }}$ & $0.003 \pm 0.002^{\mathrm{a}}$ & 7.00 & $0.973 \pm 0.010^{\mathrm{e}}$ & $0.021 \pm 0.001^{\mathrm{defg}}$ \\
\hline $\mathrm{SCO}_{2} / \mathrm{EtOH}$ & Spiddal & Summer & $0.133 \pm 0.004^{\mathrm{i}}$ & $0.002 \pm 0.004^{\mathrm{a}}$ & 6.00 & $0.798 \pm 0.003^{\mathrm{h}}$ & $0.012 \pm 0.008^{\mathrm{gh}}$ \\
\hline $\mathrm{SCO}_{2} / \mathrm{EtOH}$ & Finnavarra & Autumn & $0.139 \pm 0.003^{\mathrm{ghi}}$ & $0.003 \pm 0.003^{\mathrm{a}}$ & 3.00 & $0.417 \pm 0.007^{\mathrm{mn}}$ & $0.009 \pm 0.002^{\mathrm{gh}}$ \\
\hline $\mathrm{SCO}_{2} / \mathrm{EtOH}$ & Spiddal & Autumn & $0.147 \pm 0.008^{\text {efghi }}$ & $0.004 \pm 0.006^{\mathrm{a}}$ & 7.00 & $1.029 \pm 0.030^{\mathrm{d}}$ & $0.028 \pm 0.008^{\text {cde }}$ \\
\hline $\mathrm{SCO}_{2} / \mathrm{EtOH}$ & Finnavarra & Winter & $0.144 \pm 0.002^{\text {fghi }}$ & $0.003 \pm 0.004^{\mathrm{a}}$ & 3.00 & $0.432 \pm 0.017^{\mathrm{lm}}$ & $0.009 \pm 0.001^{\mathrm{gh}}$ \\
\hline $\mathrm{SCO}_{2} / \mathrm{EtOH}$ & Spiddal & Winter & $0.157 \pm 0.001^{\mathrm{defg}}$ & $0.005 \pm 0.001^{\mathrm{a}}$ & 3.00 & $0.432 \pm 0.015^{\mathrm{lm}}$ & $0.015 \pm 0.005^{\text {efgh }}$ \\
\hline $\mathrm{SCO}_{2}$ & Finnavarra & Spring & $0.188 \pm 0.002^{\mathrm{ab}}$ & $0.009 \pm 0.003^{\mathrm{a}}$ & 2.40 & $0.451 \pm 0.006^{1}$ & $0.022 \pm 0.004^{\operatorname{defg}}$ \\
\hline $\mathrm{SCO}_{2}$ & Spiddal & Spring & $0.196 \pm 0.030^{\mathrm{a}}$ & $0.007 \pm 0.002^{\mathrm{a}}$ & 2.30 & $0.451 \pm 0.001^{1}$ & $0.016 \pm 0.004^{\mathrm{efgh}}$ \\
\hline $\mathrm{SCO}_{2}$ & Finnavarra & Summer & $0.154 \pm 0.004^{\text {defgh }}$ & $0.003 \pm 0.003^{b}$ & 2.30 & $0.354 \pm 0.006^{\circ}$ & $0.007 \pm 0.003^{\mathrm{h}}$ \\
\hline $\mathrm{SCO}_{2}$ & Spiddal & Summer & $0.136 \pm 0.001^{\mathrm{hi}}$ & $0.003 \pm 0.001^{b}$ & 2.90 & $0.394 \pm 0.004^{\mathrm{n}}$ & $0.009 \pm 0.010^{\mathrm{gh}}$ \\
\hline $\mathrm{SCO}_{2}$ & Finnavarra & Autumn & $0.156 \pm 0.004^{\operatorname{defg}}$ & $0.002 \pm 0.006^{\mathrm{b}}$ & 5.20 & $0.811 \pm 0.010^{\mathrm{h}}$ & $0.010 \pm 0.008^{\mathrm{gh}}$ \\
\hline $\mathrm{SCO}_{2}$ & Spiddal & Autumn & $0.159 \pm 0.000^{\mathrm{def}}$ & $0.002 \pm 0.000^{\mathrm{b}}$ & 5.30 & $0.843 \pm 0.003^{\mathrm{g}}$ & $0.011 \pm 0.004^{\mathrm{gh}}$ \\
\hline $\mathrm{SCO}_{2}$ & Finnavarra & Winter & $0.194 \pm 0.006^{\mathrm{a}}$ & $0.004 \pm 0.008^{b}$ & 6.50 & $1.251 \pm 0.001^{\mathrm{b}}$ & $0.026 \pm 0.004^{\mathrm{def}}$ \\
\hline $\mathrm{SCO}_{2}$ & Spiddal & Winter & $0.164 \pm 0.010^{\text {cde }}$ & $0.003 \pm 0.000^{\mathrm{b}}$ & 5.50 & $0.902 \pm 0.005^{\mathrm{f}}$ & $0.017 \pm 0.002^{\text {efgh }}$ \\
\hline
\end{tabular}

Mean values \pm S.D. Different superscript letters (a, b, c etc) column wise indicate significant difference. 
Table 3. Fucoxanthin purity (mg fucoxanthin equivalents(FE)/mg extract), Xanthophyll purity (mg xanthophyll equivalents(XE)/mg extract) and total extract yield (mg/g dry weight extract (DWE)) of solid-liquids extracts (SLE), supercritical fluid extracts (SFE) and supercritical fluid extracts with ethanol as co-solvent, Total Fucoxanthin content (TFC) (mg TFC/g dry weight extract (DWE)) and Total Xanthophyll content (TXC) mg TXE/g dry weight extract (DWE)) of Fucus serratus over four seasons and from two harvest locations.

\begin{tabular}{|c|c|c|c|c|c|c|c|}
\hline Extract & Location & Season & $\begin{array}{c}\text { Fucoxanthin purity } \\
\text { (mg FE/mg extract) } \\
\text { Fucus serratus }\end{array}$ & $\begin{array}{c}\text { Xanthophyll purity } \\
\text { (mg XE/mg extract) } \\
\text { Fucus serratus }\end{array}$ & $\begin{array}{c}\text { Extract yield (mg/g } \\
\text { DWE) }\end{array}$ & $\begin{array}{c}\text { Total Fucoxanthin } \\
\text { content (mg TFC/g } \\
\text { DWE) in Fucus } \\
\text { serratus }\end{array}$ & $\begin{array}{c}\text { Total Xanthophyll } \\
\text { Content (mg TXC/g } \\
\text { DWE) in Fucus } \\
\text { serratus } \\
\end{array}$ \\
\hline SLE & Finnavarra & Spring & $0.139 \pm 0.006^{\mathrm{defg}}$ & $0.003 \pm 0.004^{\mathrm{d}}$ & 21.500 & $2.989 \pm 0.008^{\mathrm{i}}$ & $0.065 \pm 0.010^{\mathrm{fg}}$ \\
\hline SLE & Spiddal & Spring & $0.128 \pm 0.003^{\mathrm{gh}}$ & $0.002 \pm 0.003^{\mathrm{d}}$ & 12.400 & $1.587 \pm 0.003^{\circ}$ & $0.025 \pm 0.002^{\mathrm{hijk}}$ \\
\hline SLE & Finnavarra & Summer & $0.165 \pm 0.007^{\mathrm{abc}}$ & $0.008 \pm 0.002^{\mathrm{b}}$ & 31.500 & $5.198 \pm 0.002^{\mathrm{a}}$ & $0.252 \pm 0.003^{\mathrm{a}}$ \\
\hline SLE & Spiddal & Summer & $0.167 \pm 0.007^{\mathrm{abc}}$ & $0.016 \pm 0.001^{\mathrm{a}}$ & 10.300 & $1.720 \pm 0.004^{\mathrm{m}}$ & $0.165 \pm 0.015^{b}$ \\
\hline SLE & Finnavarra & Autumn & $0.167 \pm 0.001^{\mathrm{ab}}$ & $0.013 \pm 0.001^{\mathrm{a}}$ & 20.900 & $3.198 \pm 0.001^{\mathrm{h}}$ & $0.272 \pm 0.004^{\mathrm{a}}$ \\
\hline SLE & Spiddal & Autumn & $0.153 \pm 0.000^{\text {bcde }}$ & $0.005 \pm 0.003^{b c}$ & 25.800 & $3.535 \pm 0.015^{\mathrm{e}}$ & $0.129 \pm 0.001^{\text {cde }}$ \\
\hline SLE & Finnavarra & Winter & $0.137 \pm 0.001^{\operatorname{defg}}$ & $0.003 \pm 0.004^{\mathrm{c}}$ & 25.500 & $3.570 \pm 0.021^{\mathrm{d}}$ & $0.077 \pm 0.003^{\mathrm{f}}$ \\
\hline SLE & Spiddal & Winter & $0.129 \pm 0.001^{\mathrm{gh}}$ & $0.002 \pm 0.005^{\mathrm{d}}$ & 27.000 & $3.483 \pm 0.003^{f}$ & $0.054 \pm 0.001^{\mathrm{fg}}$ \\
\hline $\mathrm{SCO}_{2} / \mathrm{EtOH}$ & Finnavarra & Spring & $0.149 \pm 0.000^{\text {cdef }}$ & $0.005 \pm 0.000^{\mathrm{b}}$ & 31.000 & $4.619 \pm 0.004^{b}$ & $0.155 \pm 0.025^{\mathrm{bc}}$ \\
\hline $\mathrm{SCO}_{2} / \mathrm{EtOH}$ & Spiddal & Spring & $0.133 \pm 0.004^{\mathrm{fgh}}$ & $0.003 \pm 0.002^{\mathrm{c}}$ & 15.000 & $1.995 \pm 0.001^{\mathrm{k}}$ & $0.045 \pm 0.005^{\mathrm{ghi}}$ \\
\hline $\mathrm{SCO}_{2} / \mathrm{EtOH}$ & Finnavarra & Summer & $0.144 \pm 0.003^{\operatorname{defg}}$ & $0.007 \pm 0.003^{\mathrm{a}}$ & 23.000 & $3.312 \pm 0.008^{\mathrm{g}}$ & $0.161 \pm 0.002^{\mathrm{b}}$ \\
\hline $\mathrm{SCO}_{2} / \mathrm{EtOH}$ & Spiddal & Summer & $0.149 \pm 0.001^{\mathrm{h}}$ & $0.004 \pm 0.002^{c}$ & 11.000 & $1.639 \pm 0.004^{n}$ & $0.044 \pm 0.002^{\text {ghij }}$ \\
\hline $\mathrm{SCO}_{2} / \mathrm{EtOH}$ & Finnavarra & Autumn & $0.119 \pm 0.001^{\mathrm{h}}$ & $0.011 \pm 0.002^{\mathrm{a}}$ & 13.000 & $1.547 \pm 0.003^{\mathrm{p}}$ & $0.143 \pm 0.004^{\mathrm{bcd}}$ \\
\hline $\mathrm{SCO}_{2} / \mathrm{EtOH}$ & Spiddal & Autumn & $0.146 \pm 0.004^{\mathrm{def}}$ & $0.008 \pm 0.005^{\mathrm{b}}$ & 15.000 & $2.190 \pm 0.005^{\mathrm{j}}$ & $0.120 \pm 0.020^{\mathrm{de}}$ \\
\hline $\mathrm{SCO}_{2} / \mathrm{EtOH}$ & Finnavarra & Winter & $0.164 \pm 0.006^{\mathrm{abc}}$ & $0.004 \pm 0.006^{\mathrm{c}}$ & 27.000 & $4.428 \pm 0.001^{\mathrm{c}}$ & $0.108 \pm 0.002^{\mathrm{e}}$ \\
\hline $\mathrm{SCO}_{2} / \mathrm{EtOH}$ & Spiddal & Winter & $0.147 \pm 0.010^{\mathrm{def}}$ & $0.004 \pm 0.003^{c}$ & 13.000 & $1.911 \pm 0.009^{1}$ & $0.052 \pm 0.003^{\mathrm{fgh}}$ \\
\hline $\mathrm{SCO}_{2}$ & Finnavarra & Spring & $0.135 \pm 0.001^{\mathrm{fg}}$ & $0.002 \pm 0.001^{\mathrm{a}}$ & 6.800 & $0.918 \pm 0.003^{r}$ & $0.014 \pm 0.002^{\mathrm{k}}$ \\
\hline $\mathrm{SCO}_{2}$ & Spiddal & Spring & $0.147 \pm 0.001^{\mathrm{def}}$ & $0.004 \pm 0.001^{\mathrm{a}}$ & 4.900 & $0.720 \pm 0.040^{\mathrm{t}}$ & $0.020 \pm 0.003^{\mathrm{ijk}}$ \\
\hline $\mathrm{SCO}_{2}$ & Finnavarra & Summer & $0.173 \pm 0.004^{\mathrm{a}}$ & $0.001 \pm 0.004^{\mathrm{a}}$ & 6.000 & $1.038 \pm 0.004^{\mathrm{q}}$ & $0.006 \pm 0.002^{\mathrm{k}}$ \\
\hline $\mathrm{SCO}_{2}$ & Spiddal & Summer & $0.179 \pm 0.001^{\mathrm{a}}$ & $0.005 \pm 0.001^{\mathrm{a}}$ & 5.200 & $0.931 \pm 0.004^{r}$ & $0.026 \pm 0.003^{\mathrm{hijk}}$ \\
\hline $\mathrm{SCO}_{2}$ & Finnavarra & Autumn & $0.139 \pm 0.001^{\operatorname{defg}}$ & $0.003 \pm 0.001^{\mathrm{a}}$ & 5.600 & $0.778 \pm 0.002^{\mathrm{s}}$ & $0.017 \pm 0.003^{\mathrm{jk}}$ \\
\hline $\mathrm{SCO}_{2}$ & Spiddal & Autumn & $0.155 \pm 0.010^{\mathrm{bcd}}$ & $0.003 \pm 0.010^{\mathrm{a}}$ & 5.200 & $0.806 \pm 0.004^{\mathrm{s}}$ & $0.016 \pm 0.016^{\mathrm{k}}$ \\
\hline $\mathrm{SCO}_{2}$ & Finnavarra & Winter & $0.139 \pm 0.001^{\mathrm{defg}}$ & $0.001 \pm 0.001^{\mathrm{a}}$ & 4.600 & $0.635 \pm 0.005^{\mathrm{u}}$ & $0.005 \pm 0.005^{\mathrm{k}}$ \\
\hline $\mathrm{SCO}_{2}$ & Spiddal & Winter & $0.137 \pm 0.003^{\text {efg }}$ & $0.002 \pm 0.003^{\mathrm{a}}$ & 4.600 & $0.602 \pm 0.006^{\mathrm{u}}$ & $0.009 \pm 0.001^{\mathrm{k}}$ \\
\hline
\end{tabular}

Mean values \pm S.D. Different superscript letters (a, b, c etc) column wise indicate significant difference. 


\subsection{Seasonal and geographical variation of Fucoxanthin and Xanthophyll in Laminaria digitata and Fucus serratus}

In both species fucoxanthin is present at a much higher quantity than xanthophyll which is not surprising as it has been previously reported to be the main carotenoid found in brown macroalgae (Peng et al., 2011). In agreement with relative extraction potencies observed in section 3.2 the highest fucoxanthin content in Laminaria digitata was observed in the SLE extract (1.403 mg TFC/g DWE, Spiddal-Winter), however, the highest purity of fucoxanthin was observed in the $\mathrm{SCO}_{2}$ (0.196 mg FE/mg extract, Spiddal-Spring) (Table 2). The same was tend observed for the xanthophylls in the species Laminaria digitata, The highest Fucoxanthin content in Fucus serratus was also seen in the SLE extracts $(5.198 \mathrm{mg} \mathrm{TFC} / \mathrm{g}$ DWE, Finnavarra-Summer), while, the highest purity of fucoxanthin was again observed in the $\mathrm{SCO}_{2}$ extracts (Table 3). Xanthophyll quantities appeared to be greater in SLE extracts similar to trend observed for Laminaria digitata. In the present study the levels of fucoxanthin and xanthophyll over the period of a year from two harvest sites are presented in Tables 2 and 3. To date several studies on the content of photosynthetic pigments of algae have been carried out (Aguilera et al., 2002; Gudrum, 2005; Sarojini, 2009; Schmidt et al., 2010), however limited information is available on the seasonal changes that can occur in the species under investigation in the present study.

As observed in section 3.2 SLE resulted in highest total yield of fucoxanthin and xanthophyll from the species $F$. serratus therefore these levels were used as the best index for total carotenoid content when discussing seasonal/geographical variation. In the species $L$. digitata the highest total fucoxanthin content in SLE extracts was observed in winter Spiddal extract (1.403 mg TFC/g DWE), with appreciable levels also observed in the spring period. Levels were significantly $(p<0.05)$ lower in the summer period $(0.491 \mathrm{mg}$ TFC/g DWE). The xanthophyll content in the species $L$. digitata had the highest levels in the spring and the 
lowest levels in the autumn. This is in line with the purity levels observed, with the highest purity of xanthophyll observed in spring and the lowest purity in autumn. For the species $F$. serratus the highest total fucoxanthin content was observed in the summer Finnavarra sample (5.198 $\mathrm{mg}$ TFC/g DWE), the lowest level was seen in the spring Spiddal (1.587 $\mathrm{mg} \mathrm{TFC} / \mathrm{g}$ DWE). This is also the case for the purity of fucoxanthin with the highest purity observed in the summer Spiddal sample $(0.167 \mathrm{mg}$ FE/mg extract) and the lowest purity in the spring Spiddal (0.128 mg FE/mg extract). A similar trend is observed for the xanthophyll with the greatest total xanthophyll content observed in summer and the lowest level in spring. In terms of geographical variation in L. digitata, no significant $(p>0.05)$ variation in the TFC was observed between locations in the spring extracts, however variation is evident between harvest locations in summer, autumn and winter with Finnavarra having the consistently higher content. Significant $(p<0.05)$ variation in TXC is observed between both harvest sites. For the species $F$. serratus, no significant variation was observed between harvest locations in autumn and winter, but variation is seen in spring and summer with Finnavarra having the higher TFC. Again variation in TXC is observed between harvest sites.

Whilst it is most useful to discuss the effect of seasonal and geographical variation in terms of the total yield of the target compounds in SLE extracts it is also interesting to note which extraction resulted in the highest purity extracts and at what time of the year. In the species $L$. digitata the winter and spring periods appear to be the optimal season for obtaining fucoxanthin and xanthophyll in higher purity from all extracts, $\mathrm{SLE}, \mathrm{SCO}_{2} / \mathrm{EtOH}$ and $\mathrm{SCO}_{2}$. The lowest levels of fucoxanthin and xanthophyll purity were observed during the summer and autumn period in L. digitata. In general there was no significant $(p<0.05)$ difference in relation to purity observed between locations in spring, summer and autumn, however, for several of the winter samples (Laminaria digitata SLE and $\mathrm{SCO}_{2} / \mathrm{EtOH}$ and Fucus serratus $\left.\mathrm{SCO}_{2}\right)$ a difference was observed in the purity of the compounds extracted between harvest 
locations. In the L. digitata SLE winter extracts Spiddal yielded higher fucoxanthin purity ( $0.170 \mathrm{mg} \mathrm{FE} / \mathrm{mg}$ extract) than the Finnavarra sample $(0.142 \mathrm{mg} \mathrm{FE} / \mathrm{mg}$ extract $)$, this is also the case for the xanthophyll purity for the same samples. Similar results are observed in the $L$. digitata $\mathrm{SCO}_{2} / \mathrm{EtOH}$ winter samples with Spiddal samples having higher purity of both fucoxanthin $(0.157 \mathrm{mg} \mathrm{FE} / \mathrm{mg}$ extract) and xanthophyll $(0.005 \mathrm{mg} \mathrm{XE} / \mathrm{mg}$ extract) in comparison to the Finnavarra sample for the same season. In the $F$. serratus $\mathrm{SCO}_{2}$ winter samples the sample harvested from Finnavarra exhibited a higher fucoxanthin purity $(0.139$ mg FE/mg extract) in comparison to the Spiddal sample but the Spiddal sample has a greater xanthophyll purity (0.002 $\mathrm{mg} \mathrm{XE/mg} \mathrm{extract).}$

The results observed for $L$. digitata are in agreement with reports from previous studies by Stengel et al. (1998) who investigated carotenoid levels in the brown macroalgae Ascophyllum nodosum and observed that levels increased during the autumn and winter months but were significantly lower in the summer period. Similar results were also observed by Robledo (2005) where maximum carotenoid levels occurred during the cold seasons where higher precipitation occurred. Pereira (2012) also found that a higher carotenoid concentration occurred in months with less sunlight and greater nitrogen availability. Sampath-Wiley (2008) concluded that carotenoid levels were affected mainly by exposure to sun. The authors observed that shaded blades maintained high concentrations of carotenoids compared to sun exposed thalli. In the present study $F$. serrtatus summer period produced the higher content and purity of fucoxanthin. Predominantly winter and spring periods produced the lowest content and purity of both fucoxanthin and xanthophyll with little difference observed in the different harvest sites. Stengel (1998) also observed that fucoxanthin peaked during the summer period in the brown seaweed Ascophyllum nodosum, and suggested that the variation in pigments was due to differences in water depth, self-shading and enhanced nutrient limitation in the summer period. Ramus et al., (1976) also observed that 
environmental variation in light, temperature and nutrients had an influence and brought about changes in the concentration of pigments in the thallus of the seaweed investigated.

\section{Conclusion}

Solid liquid extraction at $50^{\circ} \mathrm{C}$ for $24 \mathrm{~h}$ with hexane/acetone $(70: 30)$ produced the greatest yield of carotenoid rich extracts from Fucus serratus. $\mathrm{SCO}_{2}$ at $50^{\circ} \mathrm{C}, 300 \mathrm{Atm}$ for $60 \mathrm{~min}$ produced the greatest yield of carotenoid rich extracts from Fucus serratus, however the yield was considerably lower than the SLE extracts. In contrast $\mathrm{SCO}_{2}$ produced extracts with a higher purity of fucoxanthin. This was not the case for xanthophylls where SLE produced extracts with both the highest purity and yield of xanthophylls. Seasonal variation of these carotenoids within these two macroalgae (Fucus serratus and Laminaria digitata) was also investigated for SLE extracts. Winter and spring gave the highest purity and content of fucoxanthin and xanthophyll in the species Laminaria digitata, while summer had the greatest purity and content of these compounds for the species Fucus serratus. The seasonal variation observed in the two carotenoids investigated is most likely due to the plant being exposed to diverse environmental parameters such as light, temperature and nutrients, which have influenced and brought about change in the concentration of carotenoids in the samples tested.

Pigments from seaweeds are commercially valuable in terms of food colourings, functional ingredients and also in the cosmetic industry. Therefore, the information from this study may prove to be useful in the selection of harvest times for particular compounds of interest from macroalgae and also in determining the optimal extraction technique depending on sample purity or quantity of these compounds. 


\section{Acknowledgements}

The Marine Functional Foods Research Initiative (NutraMara project) is a programme for marine based functional food development established by the Marine Institute and the Department of Agriculture, Fisheries and Food (DAFF). It is supported by funds provided under the Strategy for Science, Technology and Innovation 2006-2013 (SSTI) and the Food Institutional Research Measure (FIRM), to establish a Marine Functional Foods Research Programme. 


\section{References}

Aguilera, J., Bischof, K., Karsten, U., Hanelt, D., Wiencke, C. (2002). Seasonal variation in ecophysiological patterns in macroalgae from an Artic fjord. II. Pigment accumulation and biochemical defence systems against high light stress. Marine Biology, 140(6), 1087-1095.

Airanthi, M. W. A., Hasokawa, M., Miyashita, K. (2011). Comparative antioxidant activity of edible Japanese brown seaweeds. Journal of Food Science, 76, 104-111.

Anon. (2009).Directive 2009/32/EC of The European Parliament and of the Council. On the approximation of the laws of the Member States on extraction solvents used in the production of foodstuffs and food ingredients. L141/1- L141/9.

A.O.A.C. (1984). Official Methods of Analysis Association of Official Analytical Chemists. E. U. A. $14^{\text {th }}$ Ed. Washington, D.C. ISBN 10: 0935584242.

Barbosa, M., Valentão, P., Andrade, P. B. (2014). Bioactive Compounds from Macroalgae in the New Millenium: Implications for Neurodegenerative Diseases. Marine Drugs, 12(9), 4935-4972.

Dembitsky, V. M. and Maoka, T. (2007). Allenic and cumulenic lipids. Progress in Lipid Research, 46 (6), 328-375.

Foster, N. R., Singh, H., Jimmy Yun, S. L., Tomasko, D. L. MacNaughton, S. J. (1993). Polar and non-polar co-solvent effects on the solubility of cholesterol in supercritical fluids. Industrial and Engineering Chemistry Research, 32, 2849-2853.

Fung, A., Hamid, N., Lu, J. (2013). Fucoxanthin content and antioxidant properties of Undaria pinnatifida. Food Chemistry, 136(2), 1055-1062.

Gammone, M. A., D'Orazio, N. (2015). Anti-obesity activity of the Marine Carotenoid Fucoxanthin. Marine Drugs, 13(40, 2196-2214.

Gudrum, K., Winckem C. (2005). Photosynthesis of photosynthetic pigment and mycosporinlike amino acids after exposure of the marine red alga Chrondus crispus (Gigartinales, Rhodophyta) to different light qualities. Phycologia, 44(1), 95-102.

Hamburger, M., Baumann, D., Adler, S. (2004). Supercritical carbon dioxide extraction of selected medicinal plants. Effects of high pressure and added ethanol on yield of extracted substances. Phytochemical Analysis, 15, 46-54.

Haugan, J. A., Liaaen-Jensen, S. (1994). Algal carotenoids 54. Carotenoids of brown algae (Phaeophyceae). Biochemical Systematics and Ecology, 22(1), 31-41.

Heo, S. J., Jeon, Y. J. (2009). Protective effect of fucoxanthin isolated from Sargassum siliquastrum on UV-B induced cell damage. Journal of Photochemistry and Photobiology B, 95, 101-107.

Heo, S. J., Ko, S.C., Kang, S. M., Kang, H.S., Kang, H.S., Kim, J. P., Kim, S.H., Lee, K.W., Cho, M. G., Jeon, Y.J. (2008). Cytoprotective effect of fucoxanthin isolated from brown algae Sargassum siliqustrum against $\mathrm{H}_{2} \mathrm{O}_{2}$-induced cell damage. European Food Research and Technology, 228, 145-151. 
Heo, S. J., Yoon, W. J., Kim, K. N., Oh, C., Choi, Y. U., Yoon, K. T., Kang, D. H., Qion, Z. J., Choi, I. W., Jung, W. K. (2012). Anti-inflammatory effect of fucoxanthin derivatives isolated from Sargassum siliquastrum in lipopolysaccharides-stimulated RAW 264.7 macrophage. Food and Chemical Toxicology: an international journal published for the British Industrial Biological Research Association, 50(9), 3336-3342.

Hosokawa, M., Miyashita, T., Nishikawa, S., Emi, S., Tsukui, T., Beppu, F., Okada, T., Miyashita, K. (2010). Fucoxanthin regulates adipocytokine mRNA expression in white adipose tissue of diabetic/obese KK-Ay mice. Archives of Biochemistry and Biophysics, 504, $17-25$.

Kim, K.W., Heo, S.J., Yoon, W.J., Kang, S. M., Ahn, G. Y. T. H., Jeon, Y. J. (2010). Fucoxanthin inhibits the inflammatory response by supressing the activation of NF- $\kappa \mathrm{B}$ and MAPKs in lipopolysaccharide-induced RAW 264.7 macrophages. European Journal of Pharmacology, 649, 369-375.

Macías-Sánchez, M.D., Mantell, C., Rodríguez, M., Martínez de la Ossa, E., Lubián, L. M., Montero, O. (2005). Supercritical fluid extraction of carotenoids and chlorophyll afrom Nannochloropsis gadiatana. Journal of Food Engineering, 66, 245-251.

Macías-Sánchez, M.D., Mantell, C., Rodríguez, M., Martínez de la Ossa, E., Lubián, L. M., Montero, O. (2007). Supercritical fluid extraction of carotenoids and chlorophyll $a$ from Synechococcus sp. Journal of Supercritical Fluids, 39, 323-329.

Maeda, H., Hosokawa, M., Sashima, T., Funayama, K., Miyashita, K. (2005). Fucoxanthin from edible seaweed, Undaria pinnatifida shows anti-obesity effect through UCP1 expression in white adipose tissues. Biochemical and Biophysical Research Communications, 332, 392-397.

Maeda, H., Hosokawa, M., Sashima, T., Funayama, K., Miyashita, K. (2007). Dietary combination of fucoxanthin and fish oil attenuates the weight gain of white adipose tissue and decreases blood glucose in obese/diabetic KK-Ay mice. Journal of Agriculture and Food Chemistry, 55, 7701-7706.

Marsilis, R., Callahan, D. (1993). Comparison of a Liquid Solvent Extraction Technique and Supercritical Fluid Extraction for the Determination of $\alpha$ and $\beta$-carotene in vegetables. Journal of Chromatographic Science, 31(10), 422-428.

Mendes, R. L., Fernandes, H. L., Coelho, J. P., Reis, E. C., Cabral, J. M. S., Novais, J. M., Palavra, A. F. (1995). Supercritical $\mathrm{CO}_{2}$ extraction of carotenoids and other lipids from Chlorella vulgaris. Food Chemistry, 53, 99-103.

Miki, W. (1991). Biological functions and activities of animal carotenoids. Pure Applied Chemistry, 63, 141-146.

Miyashita, K., Nishikawa, S., Beppu, F., Tsukui, T., Abe, M., Hosokawa, M. (2011). Allenic carotenoid, fucoxanthin as a novel marine nutraceutical from brown seaweed. Journal of the Science of Food and Agriculture, 91, 1166-1174.

Mohamad, R. S.,Mansoori, G.A. (2002). The use of Supercritical Fluid Extraction Technology in Food Processing.Featured Article- Food Technology Magazine, The World Markets Research Centre, London, UK. 
Nishikawa, S., Hosokawa, M., Miyashita, K. (2012). Fucoxanthin promotes translocation and induction of glucose transporter 4 in skeletal muscles of diabetic/obese KK-A ${ }^{\mathrm{y}}$ mice. Phytomedicine, 19, 389-394.

Noh, M. J., Kim, T. G., Hang, I. K., Yoo, K. P. (1995). Measurements and correlation of effect of co-solvents on the solubilities of complex molecules in supercritical carbon dioxide. Korean Journal of Chemical Engineering, 13, 216-219.

Nomura, M., Kamogawa, H., Susanto, E., Kawagoe, C., Yasui, H., Saga, N., Hosokawa, M., Miyashita, K. (2013). Seasonal variations of total lipids, fatty acid composition and fucoxanthin contents of Sargassum horneri (Turner) and Cystoseira hakodatenis (Yendo) for the northern seashore of Japan. Journal of Applied Phycology, 25, 1159-1169.

Peng, J., Yuan, J. P., Wu, C. F., Wang, J. H. (2011). Fucoxanthin, a marine carotenoid present in brown seaweeds and diatoms: metabolism and bioactivities relevant to human health. Marine Drugs, 9, 1806-1828.

Pereira, D. C., Trigueiro, T. G., Colepicolo, P., Marinho-Soriano, E. (2012). Seasonal changes in the pigment composition of natural population of Gracilaria domingensis (Gracilariales, Rhodophyta). Revista Brasileira de Farmacognosia, 22(4), 874-880.

Ramus, J., Geale, S. I., Mauzerall, Howard, K. L. (1976). Change in photosynthetic pigments concentration in seaweeds as a function of water depth. Marine Biology, 37, 223-229.

Rizvi, S. S. H., Yu, Z. R., Bhaskar, A.R., Chidambara Raj, C. B. (1994). Fundamentals of Processing with Supercritical Fluids. Ch1 in Supercritical Fluid Processing of Food and Biomaterials. Rizvi, S. S. H. p 1-26. Chapman \& Hall, Bishopsbriggs, Glasgow.

Roh, M. K., Salim Uddin, Md., Chun, B. S. (2008). Extraction of fucoxanthin and Polyphenol from Undaria pinnatifida using Supercritical Carbon Dioxide with co-solvent. Biotechnology and Bioprocess Engineering, 13, 724-729.

Robeledo, D., Freile-Pelegrín, Y. (2005). Seasonal variation in photosynthesis and biochemical composition of Caulerpa spp. (Bryopsidales, Chlorophyta) from the Gulf of Mexico. Phycologia, 44(3), 312-319.

Sachindra, N.M., Sato, E., Maeda, H., Hosokawa, M., Niwano, Y., Kohno, M., Miyashita, K. (2007). Radical scavenging and singlet oxygen quenching activity of marine carotenoid fucoxanthin and its metabolites. Journal of Agriculture and Food Chemistry, 55, 8516-8522.

Sampath-Wiley, P., Neefus, C. D., Jahnke, L. S. (2008).Seasonal effects of sun exposure and emersion on intertidal seaweed physiology: Fluctuations in antioxidant contents, photosynthetic pigments and photosynthetic efficiency in the red alga Porphyra umbilicalis Kützing (Rhodophyta, Bangiales). Journal of Experimental Marine Biology and Ecology, 361, 83-91.

Sarojini, Y. K., Lakshmi Narayanan. (2009). Influence of environmental factors on variations in distribution of photosynthetic pigments of macroalgae. Algal Biomass, Resources and Utilization: 157-163.

Schmidt, E.C., Nunes, B. G., Maraschin, M., Bouzon, Z. L. (2010).Effect of ultraviolet-Bradiation on growth, photosynthetic pigment, and cell biology of Kappacphycus alvarezii (Rhodophyta, Gigartinales) macroalgae brown strain. Photosynthetica, 22(2), 161-172. 
Shilpi, A., Shivhare, U. S., Basu, S. (2013). Supercritical CO² Extraction of compounds with Antioxidant Activity from fruits and vegetables waste- A Review. Focusing in Modern Food Industry (FMFI), 2(1, 43-62.

Sies, H., Stahl, W. (1995). Vitamins E and C, beta-carotene, and other carotenoids as antioxidants. The American Journal of Clinical Nutrition, 62(6), 13155-13215.

Stengel, D. B., Dring, M. J. (1998). Seasonal variation in the pigment content and photosynthesis of different tallus regions of Ascophyllum nodosum (Fucales, Phaeophyta) in relation to position in the canopy. Phycologia, 37(4), 259-268.

Straub. (1987). In; Key to Carotenoids. $2^{\text {nd }}$ edition. Ed. (Pfander, H., Gerspacher, M., Rychener, M., and Schwabe, R., Eds) 1-296, Birkhäuser Verlag, Basel, Boston.

Torres, P. B., Chow, F., Furlan, C. M., Mandelli, F., Mercadante, A., Alves, D. Y., Santos, C. D. (2014).Standardization of a protocol to extract and analyze chlorophyll a and carotenoids in Gracilaria tenuistipitat Var. Liui. Zhang and Xia (Rhodophyta). Brazilian Journal of Chromatography, 62(1), 57-63.

Urikura, I., Sugawara, T., Hirata, T. (2011). Protective effect of Fucoxanthin against UVBInduced Skin Photoaging in hairless mice. Bioscience, Biotechnology and Biochemistry, 75(4), 757-760.

Woo, M. N., Jeon, S.M., Kim, H. J., Lee, M. K., Shin, S. K., Shin, Y. C., Park, Y. B., Choi, M. S. (2010). Fucoxanthin supplementation improves plasma and hepatic lipid metabolism and blood glucose concentration in high-fat fed C57BL/6N mice. Chemico-Biological Interactions, 186, 316-322.

Xiao, X., Si, X., Yuan, Z., Xu, X., Li., G. (2012). Isolation of fucoxanthin from edible brown algae by microwave-assisted extraction coupled with high-speed countercurrent chromatography. Journal of Separation Science, 35, 2313-2317.

Yasushi, K. (1991). New Trends in Photobiology: Structures and functions of carotenoids in photosynthetic systems. Journal of Photochemistry and Photobiology B: Biology, 9(3-4), 265-280. 
Fig 1.Yield of carotenoid extract expressed as $\mathrm{mg} / \mathrm{g}$ extract of Fucus serratus following SFE extraction over a $105 \mathrm{~min}$ time period at a temperature of $50^{\circ} \mathrm{C}$, a pressure of $300 \mathrm{Atm}$ and a flow rate of $1 \mathrm{ml} / \mathrm{min}$.

Fig 2. Yield of carotenoid determined by HPLC (sum of fucoxanthin and xanthophyll) and expressed as percentage of the total extract yield following SFE extraction at three temperatures $\left(40,50 \& 60^{\circ} \mathrm{C}\right)$ and three pressures $(150,225 \& 300 \mathrm{Atm})$ for $60 \mathrm{~min}$ from the species Fucus Serratus.

Fig 3. HPLC chromatogram (450nm) of the optimised SFE extraction from Fucus serratus. Peak assignment; (a) fucoxanthin, (b) xanthophyll.

Fig 4. HPLC chromatogram (450nm) of the optimised SFE and co-solvent (ethanol)

extraction from Fucus serratus. Peak assignment; (a) fucoxanthin, (b) xanthophyll

Fig 5. HPLC chromatogram (450nm) of the optimised SLE extraction from Fucus serratus. Peak assignment; (a) fucoxanthin, (b) xanthophyll. 


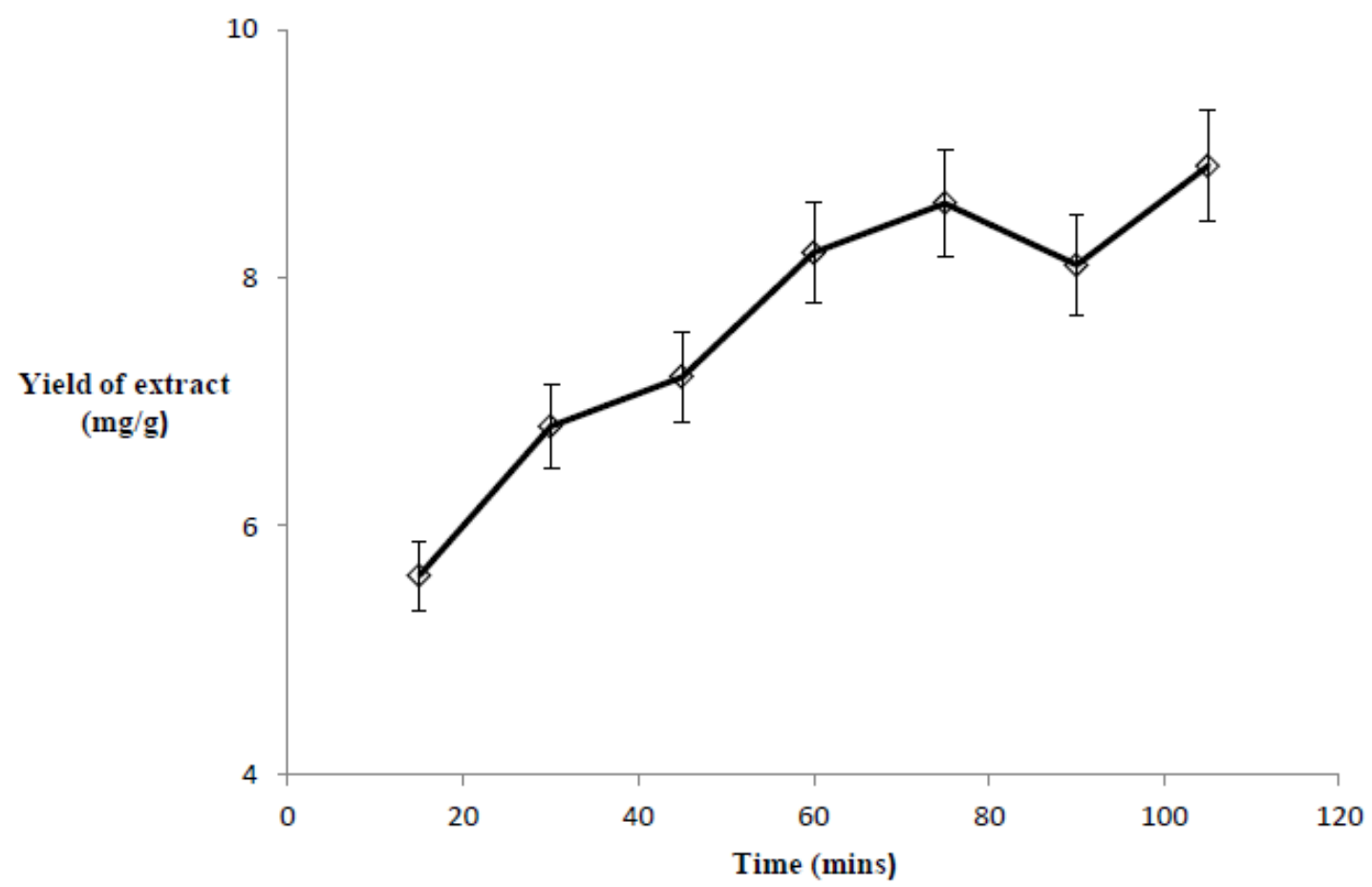

Figure 1 


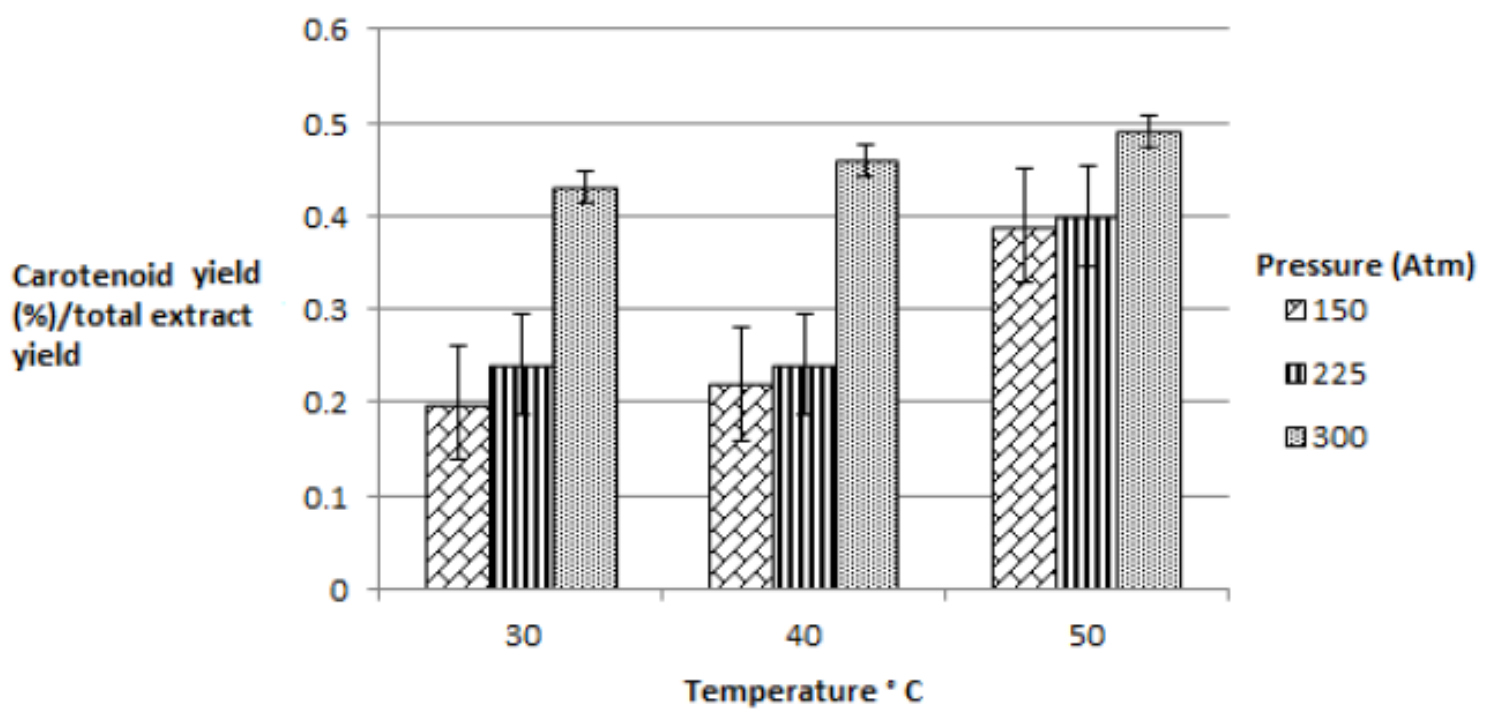

Figure 2 


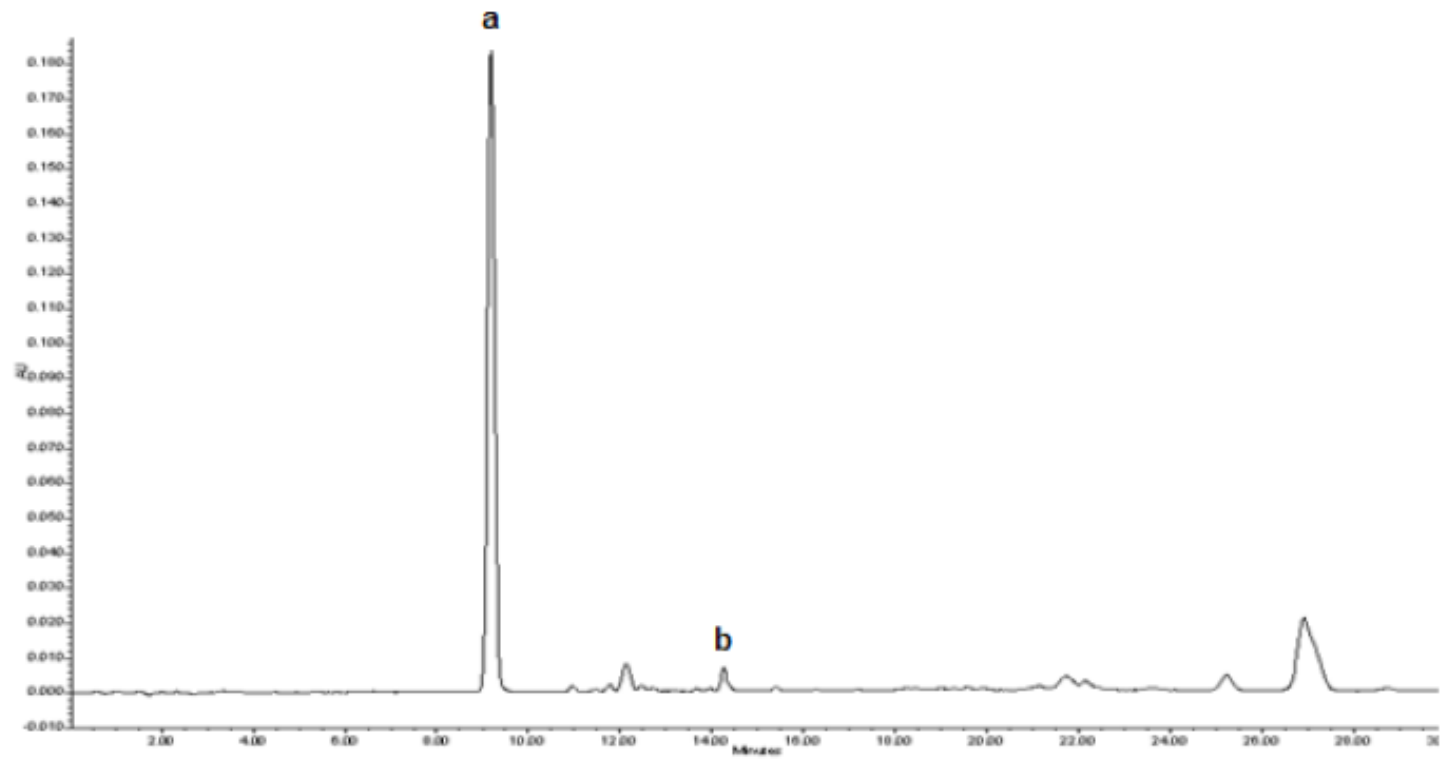

Figure 3

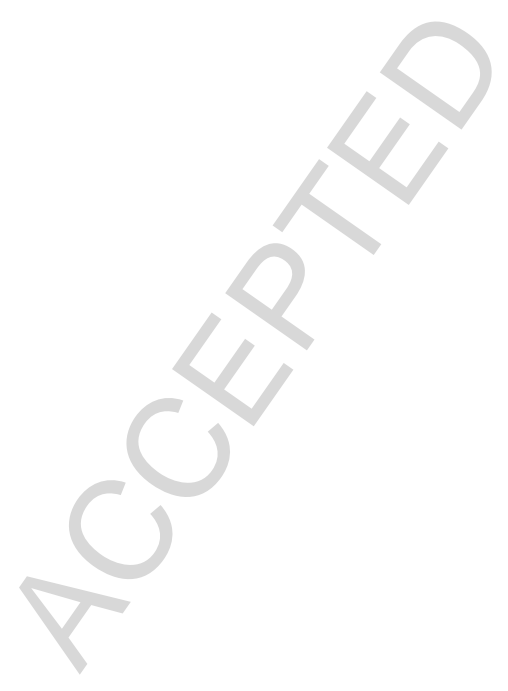




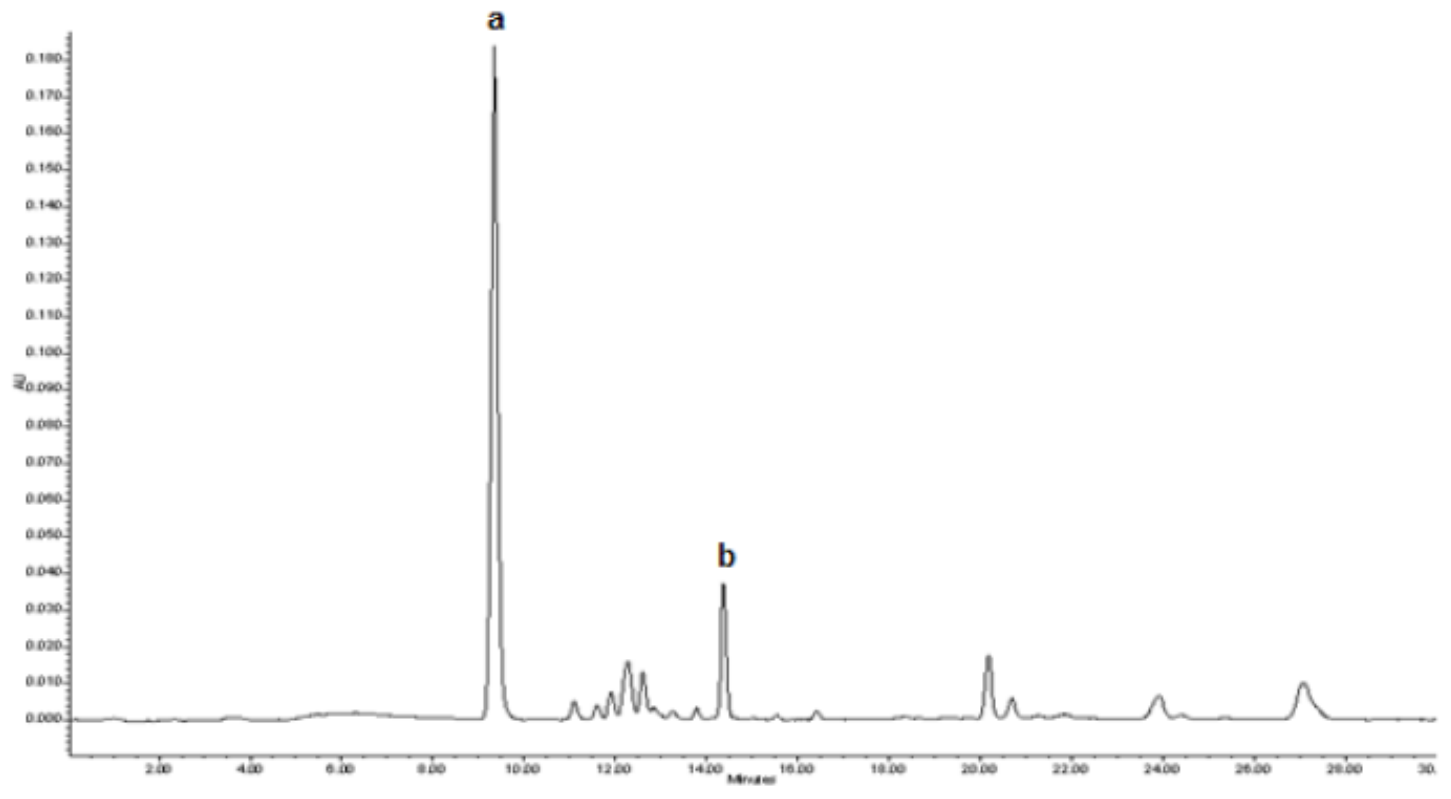

Figure 4 


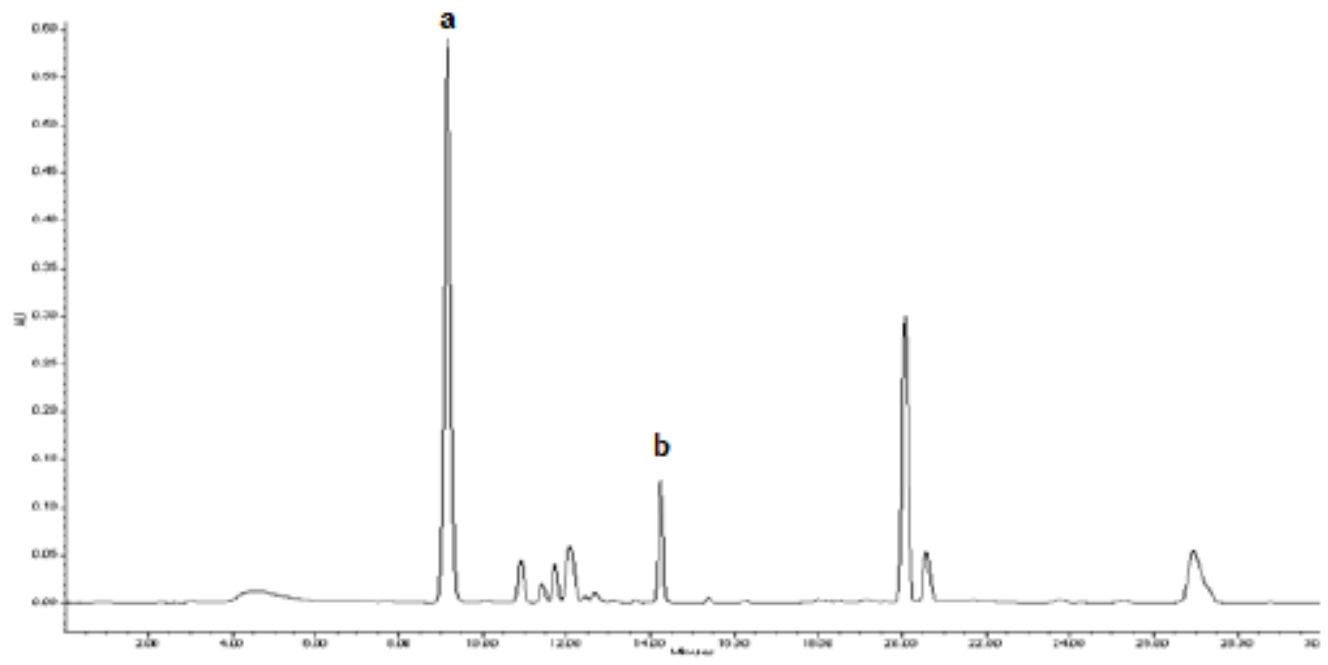

Figure 5 


\section{Highlights}

- Solid/liquid extraction (SLE), supercritical $\mathrm{CO}_{2}$, supercritical $\mathrm{CO}_{2}$ with ethanol as cosolvent for the recovery of the carotenoids, xanthophyll and fucoxanthin, from two brown macroalgae Fucus serratus and Laminaria digitata were explored.

- SLE produced the greatest yield of fucoxanthin.

- Supercritical $\mathrm{CO}_{2}$ yielded extracts with the highest purity of fucoxanthin

- Seasonal/spatial information on yields and purity for optimal harvest reported. 